\title{
Readiness for action in emergency circumstances in professional activities of penal system employees
}

\author{
Tatiana Vasilievna Kirillova ${ }^{1 *}$, Elena Sergeevna Lobanova ${ }^{2}$, Vasily Vasilyevich \\ Smykovsky ${ }^{3}$, and Maksim Sergeevich Machekhin ${ }^{4}$ \\ ${ }^{1}$ Research Institute of the Federal Penal Service of Russia, Moscow, Russia \\ ${ }^{2}$ Vologda Institute of Law and Economics of the Federal Penal Service of Russia, Department of \\ Legal Psychology and Pedagogy, Vologda, Russia \\ ${ }^{3}$ Directorate of the FPS of Russia across the Arkhangelsk region, Arkhangelsk, Russia \\ ${ }^{4}$ Perm Institute of the Federal Penal Service of Russia, Department of Regime and Security in prisons, \\ Perm, Russia
}

\begin{abstract}
Correctional facilities are created to implement penalties for persons who have committed criminal offences. Consequently, persons held in them are often socially dangerous, criminally infected and inclined to deviant behavior. At the same time, the isolation, restriction of discretion and movement, the need to stay for a long time in a certain group of people are triggering factors and cause such conditions as boredom, irritation, apathy, depression, emotional instability. These circumstances do not exclude the occurrence of emergencies caused by a violation of standards and rules of conduct by persons sentenced to imprisonment, as evidenced by the facts recorded in penitentiary practice. Working in such conditions imposes special requirements to employees. In respect thereof, particular attention is paid to the need for penal system employees to be ready for emergency circumstances. This type of readiness is complex and includes motivationally interdependent will, cognitive and activity components. The formation of the given components depends on a number of external and internal factors. While preparing staff for professional tasks in emergency circumstances, it is rather important to pay attention not only to personal, but also to the collective readiness of staff units. The staff readiness to emergencies contributes to the effective service tasks execution, increases the sense of self-confidence in staff and their authority among colleagues, and affects the nature of professional communication.
\end{abstract}

Keywords: penal system, emergency circumstances, special tactical training, attitude

\section{Introduction}

In the current conditions of the domestic penal system, the problem of preventing crimes committed by convicts in correctional facilities is quite acute. Employees of the penal and

\footnotetext{
* Corresponding author: tatiana-kirillova@ rambler.ru
} 
correctional system (hereinafter referred to as the PCS), represented by operational, regime and educational services, are obliged to prevent unlawful actions by citizens in places of deprivation of liberty.

Apart from the usual tasks established by law, due to the international implications, increased terrorist threats, attempts to discredit the Federal Penal Service of the Russian Federation in the society and on television, optimization of the number of employees of the penal system and other phenomena, in the functioning process of the PCS facilities may arise situations that require special attention and some provisional measures. Therefore, the increased attention should be paid to the tactics of the territorial and correctional personnel in emergency circumstances and to the methods of its improvement [1]. According to the Federal Constitutional Law of May 30, 2001, No. 3-FKZ "On state of emergency" [2], emergency circumstances refer to circumstances that constitute an immediate threat to the life and security of citizens or to the constitutional order of the Russian Federation and whose elimination is impossible without the application of emergency measures. Criminal emergencies include riots, hostage-taking, terrorist acts and other social processes and phenomena requiring special organizational, legal and other measures from the federal executive bodies. [3].

The work in non-standard conditions that pose a threat to the life and health of employees implies special requirements for their professional training and psychological qualities. Therefore, the concept of readiness for emergency circumstances and its development among PCS staff becomes relevant.

\section{Results and discussion}

A number of penitentiary researchers believe that the definition of "emergency circumstances" combines two terms: "emergency situations" and "emergency incidents," where the first term is understood as an unfavourable situation caused by circumstances of a natural and man-made character, and the second as short-term and single events, usually of a criminal nature, disrupting the correct work of penal facilities [4].

Turning to the domestic penal system, it should be mentioned that the most common emergency circumstances are the following: escapes of convicted, suspected and accused persons from custody or convoying; riots and group disobedience, expressed through the active hooliganism on the territory of the correctional facility; hostage-taking by convicts; armed attacks against the protected site, service facilities, employees of the institution; another natural, man-made and biological and social emergencies.

According to media reports, in 2019 alone, 13 group disobediences were committed by convicts in correctional facilities (mainly related to a hunger strike or personal injury (selfinjury)) [5].

Official legislation pays special attention to this problem. Mainly concerning not only the suppression of the similar situations already arisen, but also the prevention and avoidance of the above-mentioned emergency circumstances.

Among them are factors that can lead to the occurrence of emergency incidents and circumstances in the facilities: external (natural disaster), as well as internal (riots, group disobedience, escapes of convicts from custody, etc.) [6]. Special risks are often created by purposely planned actions aimed at destabilizing the activities of correctional facilities. That was demonstrated at the Main Directorate of the Federal Penal Service of Russia in the Republic of Bashkortostan in 2015, and at the Main Directorate of the Federal Penal Service of Russia in the Irkutsk Region in 2020. Based on an analysis of the service activities of the territorial bodies of the Federal Penal Service of Russia, a number of group disobediences and riots committed in penal institutions can be noted. With a decrease in the number of persons in detention, the number of crimes committed by them does not only stabilize, least 
of all decrease, but even tends to increase. In 2014-2019, the number of such crimes respectively amounted to $861,940,960,977,1025,1151$ [7]. It should be noted that this dynamics is also characteristic of crimes with an increased degree of public danger. Thus, the number of crimes under article 321 of the Criminal Code of the Russian Federation "Disorganization of the activities of facilities providing isolation from society" committed in correctional colonies during the specified period respectively amounted to 158, 166, 194, $180,192,238$ [8].

For employees of facilities of the Federal Penal Service of Russia, it is necessary to distinguish the concept of "actions in case of emergency circumstances". In science and practice, it refers to the activities of the PCS personnel in the event of riots, the release of hostages, the escapes, the elimination of the explosions hazard, the attack defense, causing the necessity to use weapons, special means, apply special tactics and other force methods against the people in detention [9].

The PCS personnel must act confidently in a difficult operational environment. To provide this, it is important to have an effective staff training system [10]. In the author's opinion, preparation for action in case of emergency circumstances, shall be carried out in classes of tactical and special training. Tactical and special training involves the focused process of training employees, management bodies, integrated units in actions in case of emergency circumstances.

In the case of high-quality training within the framework of tactical and special training, the readiness of personnel to emergencies increases.

It is believed that readiness for action in the event of emergency circumstances is necessary for everyone to not be taken by surprise, not to become their victim, to correctly fulfill their functional duties, and especially for those who work in difficult conditions [11]. The fundamental condition for the success of the tasks realizations in the PCS is the readiness of the staff to fulfill them. The occurrence of a readiness state begins with the understanding of the task received, determining the motives and necessity for its implementation. Then there is an assessment of the situation, an assessment of the own forces, an assessment of the criminal, the determination of the nearest task, a further task, the development of a task implementation plan, models for its implementation, arrangement of future actions.

It is believed that emergency readiness is a dynamically variable structure with the complex formation and functional relationships among its components. When performing service tasks, the employee on the basis of internal activity (biological, physiological and mental) achieves certain goals [12, p. 204].

The content and structure of readiness are determined by the task performed, the operational situation, the type of equipment, weapons and special equipment used, the degree of readiness of the opposing side for active actions and other factors.

The readiness of the PCS employee to act in an emergency is expressed in his/her desire and motivation to fulfill a significant goal through willpower, to influence such components of his/her psyche as fears, instinct for self-preservation, selfishness, established behaviors. A staff member ready for the task should have sufficient willpower, awareness of the need to carry out the task and increased responsibility [13].

The increased level of readiness is determined by the employees' deep awareness of the goals of the upcoming actions, personal readiness to perform tasks and inflexible will to win, deep knowledge of special tactics, high physical condition, psychological stability, the effectiveness of the management system, confidence in the correctness of their superiors, a high level of moral and will qualities, comprehensive resource provision, corresponding to the needs and demands of employees, carrying out a set of measures to restore the combat effectiveness of forces and means, including psychological rehabilitation and restoration of spiritual forces. 
The most significant indicators of readiness for emergencies are targeted mobilization of mental processes, properties, experience, their concentration on fulfillment of the obtained task and ways of its execution, availability of attitudes for maximum use of forces and means in order to overcome difficulties and achieve the set goal [14].

Works of Kugno [15, p. 49] have shown that the following factors are necessary for the creation of a state of readiness among employees for complex activities. As a result, the employee is set up to perform the received task and achieve the goal.

It is logical to consider the readiness of employees to act in emergencies as the variable degree of stable prerequisites for various personality conditions, including mental and physiological ones. Practice shows that the main and important indicators of the level of staff readiness for service are the existing internal affirmation of the staff member to perform the service tasks; conditions of preparation for the performance of service duties together with the organizational activity of the head; the mood in which the employee arrived at the service [16].

In our opinion, the essential definition of the readiness of employees for actions in case of emergency includes not only the personal readiness of the PCS employee for actions in an extreme situation, but also collective readiness. This could represent in performing a task as a part of a unit, for example, in case of eliminating riots, suppressing convicts group disobedience. In such cases, the success of the task completed depends on the quality of each person's actions. If one of the participants shows cowardice, irritability, depressed mood, signs of distress, either psychological infection or a disagreement with the necessary interaction can occur. In both cases, the risk of unsuccessful performance of the task assigned to the unit increases.

The team readiness is not a direct consequence or the sum of readiness of individual members. Its readiness is also influenced by public opinion, collective traditions, general mood and attitudes, the orientation of clear and hidden leaders. The readiness of the team is revealed in the general purpose, orientation, general will, collective skills, special coherence of actions, setting for the unquestionable and unfailing implementation of the superior's orders.

\section{Conclusion}

Thus, readiness for action in case of emergency circumstances in relation to the staff of the Federal Penal Service should be understood as a state formed on the basis of acquired knowledge, skills, qualities and ensuring the performance of service duties in case of aggravation of the operational situation at the facilities of the penal system. The readiness of employees of institutions of the Federal Penal Service of Russia in the current conditions of aggravation of criminal situation becomes especially relevant. Often, it is the high level of readiness for action in case of an emergency that allows employees to stop or eliminate it. The readiness of employees to act in case of emergency also contributes to the establishment of professionally competent relations in the team and is a regulator of the effectiveness of their further activity.

\section{References}

1. S. Galani, Human Rights Law Rev. 19(1), 149-171 (2019)

2. Federalnyi konstitutsionnyi zakon ot 30.05.2001 N 3-FZ (red. ot 03.07.2016) "O chrezvychainom polozhenii" [Federal Constitutional Law of 30.05.2001 No. 3-FKZ (ed. dated 03.07.2016) "On State of Emergency"] (2016)

3. A.V. Snegovoy, Russian Min. Internal Aff. Admin. Acad. 4, 40 (2012) 
4. I.A. Antonov, V.A. Antonova, Vestn. St.Pet. Univers. Min. of Internal Aff. Rus. 4, 108 (2007)

5. Media-zona. Elektronnyi zhurnal [Media zone: electronic journal]. Accessed on: March 21, 2021. [Online]. Available: http: https://zona.media/article/2018/06/08/riot-report10

6. A. Wilner, A. Jeffery, J. Lalor, A. Rosolska, C. Yorgoro, Compar. Strat. 38(4), 347370 (2019)

7. FSIN Rossii [Federal Penitentiary Service of Russia] Accessed on: March 21, 2021. [Online]. Available: http://fsin.su/statistics/

8. V.A. Utkin, Problemy teorii ugolovnogo nakazaniya: kurs lektsii [Problems of the criminal penalties theory: course of lectures] (Tomsk, 2018)

9. A. Garipova, A. Askhamov, V. Martynova, S. Sharifullina, Astra Salvensis, 655-662 (2017)

10. O. Kirillova, I. Gavrilova, T. Kirillova, N. Pugacheva, N. Safin, L. Safina, T. Khalmetov, J. Leg., Ethi. and Regul. Iss. 21(3) (2018)

11. Y. Thomas, Phys. Sportsmed. 7(4), 59-68 (1979)

12. N.I. Sarzhveladze, Lichnost i ee vzaimodeistvie s okruzhayushchei sredoi [Personality and its interaction with the environment] (Tbilisi, 1989)

13. S. Loertscher, D. Milton, Democr. and Secur. 14(1), 1-23 (2018)

14. G.D. Lukov, K.K. Platonov, Psikhologiya [Psychology] (Moscow, 1964)

15. E.E. Kugno, Formirovanie gotovnosti lichnosti k deyatelnosti v ekstremalnykh situatsiyakh [Formation of personal readiness for activity in extreme situations], $\mathrm{PhD}$ thesis (Ulan-Ude, 2013)

16. S. Ausset, et al. Crit. Care 20(1), 88 (2016) 